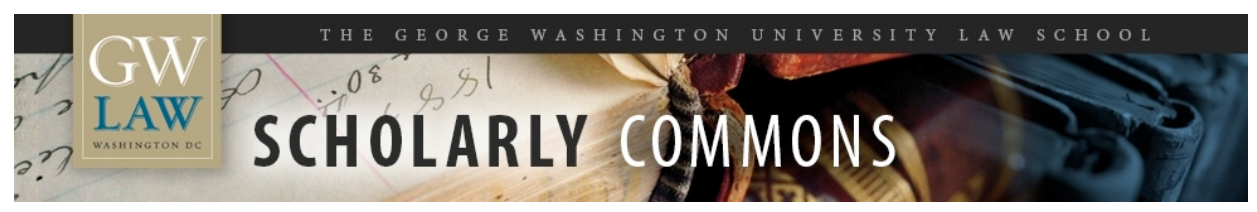

\title{
The World Bank's Procurement Framework: An Assessment of Aid Effectiveness
}

\author{
Christopher R. Yukins \\ George Washington University Law School, cyukins@law.gwu.edu
}

Sope Williams-Elegbe

Follow this and additional works at: https://scholarship.law.gwu.edu/faculty_publications

Part of the Law Commons

\section{Recommended Citation}

Yukins, Christopher R. and Williams-Elegbe, Sope, The World Bank's Procurement Framework: An Assessment of Aid Effectiveness (2018). Christopher Yukins \& Sope Williams-Elegbe, The World Bank's Procurement Framework: An Assessment of Aid Effectiveness, in Public Procurement and Aid Effectiveness: A Roadmap Under Construction (Annamaria La Chimia \& Peter Trepte eds., 2019) (discussion draft) (forthcoming April 2019). ; GWU Law School Public Law Research Paper No. 2018-37; GWU Legal Studies Research Paper No. 2018-37. Available at SSRN: https://ssrn.com/abstract=3237807

This Chapter is brought to you for free and open access by the Faculty Scholarship at Scholarly Commons. It has been accepted for inclusion in GW Law Faculty Publications \& Other Works by an authorized administrator of Scholarly Commons. For more information, please contact spagel@law.gwu.edu. 
DISCUSSION DRAFT: AUGUST 2018

Forthcoming chapter in:

Public Procurement and Aid Effectiveness: A Roadmap Under Construction

(Annamaria La Chimia \& Peter Trepte, eds., Hart Publishing 2018)

https://www.bloomsbury.com/au/public-procurement-and-aid-effectiveness-9781509922451/

\title{
The World Bank's Procurement Framework: An Assessment of Aid Effectiveness
}

\author{
Christopher R. Yukins \\ Lynn David Research Professor of Public Procurement Law and \\ Co-Director, Government Procurement Law Program \\ George Washington University Law School \\ Sope Williams-Elegbe \\ Professor in the Department of Mercantile Law and \\ Deputy Director, African Procurement Law Unit \\ Stellenbosch University
}

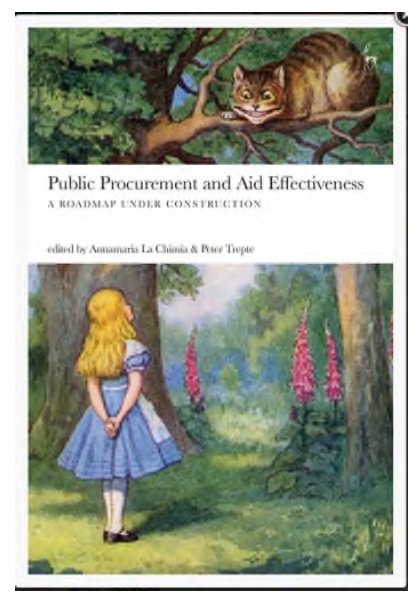

In 2016, the World Bank formally implemented a massive reform ${ }^{1}$ of the guidance it applies to procurements conducted under World Bank-financed projects. ${ }^{2}$ Other multilateral development banks have followed the World Bank's example in harmonizing their procurement rules to those of the World Bank in the past, ${ }^{3}$ and so the Bank's new Procurement Framework is likely to shape the procurement policies of the other multilateral development banks, ${ }^{4}$ as well as other international institutions. Moreover, because of the prominent role that the World Bank plays in shaping procurement policy, the Bank's reforms have had a profound impact on procurement in many countries around the world. ${ }^{5}$

The Bank's reforms involved a "once-in-a-generation systematic reform and culture change," with a new emphasis on capacity-building in borrower nations and "hands-on" implementation support from the Bank, as well as oversight through Bank guidance and

\footnotetext{
${ }^{1}$ See, e.g., Collin Swan \& Sati Harutyunyan, Multilateral Development Banks In An Era Of Procurement Reform: How Larger Development Goals Are Shaping Revamped Approaches To Procurement, 58 Govt Contractor $\mathbb{I}$ 111(Apr. 6, 2016), available at https://papers.ssrn.com/sol3/papers.cfm?abstract_id=2760059.

${ }^{2}$ For an overview of how the World Bank manages its financed projects through the project cycle and the procurement process, see Sope Williams-Elegbe, Public Procurement and Multilateral Development Banks, ch. 5 (Hart Publishing 2017).

${ }^{3} I d$. at 59 (discussing other multilateral development banks' harmonizing efforts to follow World Bank's earlier procurement guidelines).

${ }^{4}$ In 2015, as the World Bank's reforms were unfolding, the African Development Bank announced approval of its own new procurement framework, which is built on many of the same policies that undergird the World Bank's Procurement Framework. See, e.g., African Development Bank, Press Release: AfDB Approves the New Bank Group Procurement Framework, Oct. 14, 2015 (Board of Directors of the African Development Bank Group approved the Bank's new procurement framework), available at https://www.afdb.org/en/news-and-events/afdbapproves-the-new-bank-group-procurement-framework-14817/.

${ }_{5}^{5}$ See, e.g., Sope Williams-Elegbe, The World Bank's Influence on Procurement Reform in Africa, 21.1 African J. Int'l \& Comp. L. 95 (2013).
} 
regulations. ${ }^{6}$ The reforms were built on strikingly novel statements of policy, and included new procurement regulations to implement the many reforms, from enhanced complaints procedures to improved competitive procedures.

\section{Measures of Aid Effectiveness}

The Bank's reforms were done against a backdrop of strong demands from across the world to improve the "effectiveness" of development aid. ${ }^{7}$ Those concerns were synthesized in two landmark documents, the Paris Declaration on Aid Effectiveness (2005) and the Accra Agenda for Action (2008). ${ }^{8}$ With regard to capacity in procurement for development, ${ }^{9}$ the Paris declaration called for:

- Strengthening partner (i.e., recipient) nations' operational frameworks and capacities in their own country systems (including their procurement systems);

- Respecting and bolstering partner nations' leadership in their development;

- Reducing redundancies due to special demands from donors; instead, donors committed to use "country systems and procedures to the maximum extent possible";

- Fighting corruption and a lack of transparency, which erode public support, slow mobilization, and divert vital resources;

- Setting mutually agreed frameworks to allow reliable assessments of country systems;

- Specifically with regard to procurement, donors and partner nations pledged to strengthen national procurement systems and support reforms, and to use mutually agreed standards and processes for assessment; donors committed to "[p]rogressively rely on partner country systems for procurement when the country has implemented mutually agreed standards and processes."

The Accra Agenda for Action followed on the Paris Declaration. The Accra Agenda confirmed that donors would "strengthen and use developing country systems to the maximum extent possible," and would work to ensure "that their procurement procedures are transparent and allow local and regional firms to compete." 10 Donors and developing countries were to

\footnotetext{
${ }^{6}$ World Bank, Procurement in World Bank Investment Project Financing -- Phase II: The New Procurement Framework, at 1-4 (June 11, 2015), available at https://wbnpf.procurementinet.org/sites/default/files/Board-Paperphase-ii-the-new-procurement-framework.pdf.

${ }^{7}$ For a broader discussion of the aid effectiveness agenda and its effect on the multilateral development banks' policies, see Sope Williams-Elegbe, supra note 2, ch. 9, The Aid Effectiveness Agenda: Harmonisation, Tied Aid and the Use of Country Systems.

${ }^{8}$ Available at $\mathrm{http}: / / \mathrm{www} .0 e c d . o r g / \mathrm{dac} /$ effectiveness/parisdeclarationandaccraagendaforaction.html.

${ }^{9}$ See, e.g., Bodo Ellmers, European Network on Debt and Development, How To Spend It: Smart Procurement for More Effective Aid (Sept. 2011) (report based on six country case studies on procurement, aid untying and using country systems), available at http://eurodad.org/files/pdf/4639-how-to-spend-it-smart-procurement-for-moreeffective-aid-.pdf.

${ }^{10}$ See, e.g., African Development Fund, Implementing the Paris Declaration Commitments and Building on the Accra Agenda for Action: Background Paper (ADF-11 Mid-Term Review, Oct. 2009, Helsinki, Finland), available at https://www.afdb.org/fileadmin/uploads/afdb/Documents/GenericDocuments/BP\%20Implementing\%20Paris\%20Accra.FINAL.EN.pdf.
} 
respect agreed anti-corruption principles, including those under the UN Convention Against Corruption. Developing nations also were to fight corruption by "improving systems of investigation, legal redress, accountability and transparency in the use of public funds."

Using the Paris Declaration and the Accra Agenda for Action as background to assess the World Bank's recent procurement reforms as a matter of "aid effectiveness" this chapter focuses on key aspects of the reforms. The chapter proceeds in six parts. In Part II, the chapter provides a short history of the 2016 reforms. In Part III, the chapter reviews the key principles that frame the reforms. In Part IV, the chapter reviews the implementing guidance and regulations. Part V reviews new challenges which may emerge, given the trajectory of the Bank's reforms. Summing up the Bank's new measures, Part VI concludes by assessing how these procurement reforms may, on balance, affect aid effectiveness in the Bank's projects in the coming years.

\section{History of the Reforms}

The World Bank was established by the Bretton Woods Agreement, to provide reconstruction aid in the wake of the destruction of World War II. ${ }^{11}$ The World Bank includes 189 member countries, represented by the Board of Governors, who are generally the finance ministers for member nations and who meet once a year. The Board of Governors delegates specific duties to 25 Executive Directors, who work on-site at the Bank. The nations that are the largest shareholders in the Bank each appoint their own executive directors, while the other member countries are represented by elected executive directors. The Executive Directors make up the Board of Directors of the World Bank, and they oversee high-level policymaking at the Bank -- including policies regarding procurement. ${ }^{12}$

The World Bank Group is made up of five institutions, two of which are the focus of the procurement policies reviewed in this chapter: the International Bank for Reconstruction and Development (IBRD), which typically lends to middle-income countries, and the International Development Agency (IDA), which provides grants and interest-free loans to the poorest countries. When the World Bank provides support for projects through these institutions, it requires that the resulting procurements be conducted under certain policies and procedures mandated by the Bank. ${ }^{13}$

The World Bank launched the use of International Competitive Bidding (ICB) in 1951, and then promulgated procurement guidelines for use on its funded projects, founded on the Bank's fiduciary obligations ${ }^{14}$ to ensure sound management of its funds pursuant to its Articles

\footnotetext{
${ }^{11}$ World Bank, History, http://www.worldbank.org/en/about/archives/history.

${ }^{12}$ See generally World Bank, Organization, http://www.worldbank.org/en/about/leadership.

${ }^{13}$ See Sope Williams-Elegbe, The Changes to the World Bank's Procurement Policy and the Implications for African Borrowers, 1 African Pub. Proc. L.J. 22 (2014).

${ }^{14}$ As the World Bank's new Procurement Regulations note, the "Bank is required by its Articles of Agreement to 'make arrangements to ensure that the proceeds of any loan are used only for the purposes for which the loan was granted, with due attention to considerations of economy and efficiency and without regard to political or other noneconomic influences or considerations."' World Bank, Procurement Regulations for IPF Borrowers $\$ 1.2$ (July 2016, rev. Nov. 2017).
} 
of Agreement. ${ }^{15}$ The Bank issued its first written procurement rules to provide guidance for staff in 1961, and in 1964 the first formal instructions on their use were approved by the Bank's Board of Executive Directors. The first formal instructions on selecting consultants, used primarily for large engineering projects, were issued in 1966, ${ }^{16}$ and the Bank began requiring the use of standard bidding documents in the $1993 .{ }^{17}$

As these processes evolved over the decades, the Bank began to employ a "no objection" device for approving procurement methods and outcomes. ${ }^{18}$ Because the Bank is not a party to the procurement contract -- it is only a bank, or financier -- the Bank formally does not "approve" a procurement approach, but does not object: the Bank provides a formal notice of "no objection" at critical junctures in the acquisition process. ${ }^{19}$

By 2012, when the latest reforms launched, the World Bank had developed two sets of guidelines ${ }^{20}$ for borrowers to follow when conducting procurement in Bank-financed projects: (1) the "Procurement Guidelines" (known colloquially as the "red book," because of the color of the booklet's cover), which governed the procurement of goods, works, and non-consulting services, ${ }^{21}$ and the "green book," the guidelines that were to be used when consulting services were procured. ${ }^{22}$ Over many decades, the world procurement community relied on these guidelines extensively, both for use in World Bank projects ${ }^{23}$ and as templates for broader procurement reform. At the same time, though, the guidelines were often criticized ${ }^{24}$-especially the "red book," for too narrowly emphasizing competitions based on low-price, not best value -- and in 2011, when the guidelines were updated, the World Bank decided to launch a review of its procurement policies. ${ }^{25}$ As the Bank put it, though for "over 50 years the Bank's procurement approach ha[d] been a model of good international practice," as "procurement has

\footnotetext{
${ }^{15}$ See, e.g., Peter Trepte, All Change at the World Bank? The New Procurement Framework, 2016 Pub. Proc. L. Rev. 121, 122 (discussing history and Articles of Agreement).

${ }^{16}$ World Bank, Operations Policy \& Country Services, The World Bank's Procurement Policies and Procedures: Policy Review -- Initiating Discussion Paper 1-2 (Mar. 29, 2012) [hereinafter “Initiating Discussion Paper”], http://siteresources.worldbank.org/INTECA/Resources/257896-1335553632562/Initiating-Discussion-PaperEng.pdf.

${ }^{17}$ Id. at 3 .

${ }^{18}$ Id. at 2 n.4

${ }^{19}$ For an example of how the "no objection" process worked in World Bank-financed procurements before the reforms implemented in 2016, see, e.g., World Bank, The World Bank Operations Manual: Bank Procedures -Procurement, BP 11.11 (Jan. 2011, revised Apr. 2013), http://web.worldbank.org/archive/website01541/WEB/IMAGES/BP11 0-5.PDF.

${ }^{20}$ See, e.g., Sope Williams-Elegbe, supra note 2, at 58-64.

${ }^{21}$ See, e.g., World Bank, Guidelines: Procurement of Goods, Works, and Non-Consulting Services under IBRD Loans and IDA Credits by World Bank Borrowers (2014), http://pubdocs.worldbank.org/en/492221459454433323/Procurement-GuidelinesEnglishJuly12014.pdf.

${ }^{22}$ See, e.g., World Bank, Guidelines: Selection and Employment of Consultants under IBRD Loans and IDA Credits by World Bank Borrowers (2011, rev. 2014), http://siteresources.worldbank.org/INTPROCUREMENT/Resources/Consultant_GLs_English_Final_Jan2011_Revi sed_July1_2014.pdf.

${ }^{23}$ See, e.g., Allen Green, International Government Contract Law $§ 5: 5$ (West 2017) (available on Westlaw).

${ }^{24}$ See, e.g., Whitney Debevoise \& Christopher Yukins, Assessing The World Bank's Proposed Revision Of Its Procurement Guidelines, 52 Gov. Contr. II 180 (2012).

${ }^{25}$ See Initiating Discussion Paper, supra note 16, at viii.
} 
matured as a profession in an environment of globalization and rapid information exchange, the Bank's global procurement leadership ha[d] fallen behind good international practice and need[ed] to be modernized."26

After several years of preparations ${ }^{27}$ and meetings with thousands of shareholders, ${ }^{28}$ including governments, representatives of the private sector, trade bodies, Civil Society Organizations (CSOs) and Non-Governmental Organizations (NGO's), ${ }^{29}$ the World Bank's Board of Executive Directors approved the new Procurement Framework, ${ }^{30}$ which became effective in July 2016.

\section{Central Principles of the New Procurement Framework}

The reforms launched in 2011 ultimately went far beyond merely revising the World Bank's Procurement Guidelines. Framed as a new "procurement framework" which took effect in July $2016,{ }^{31}$ the reforms marked, in many ways, entirely new approaches for the World Bank, and for the broader development community. While the World Bank's new procurement framework is implemented through a complex suite of documents available on the World Bank website, the key principles that underpin the new framework are set forth in a master policy statement, Bank Policy: Procurement in IPF (Investment Project Financing) and Other Operational Procurement Matters. ${ }^{32}$

The Bank's policy document explains the core principles and goals of the new procurement framework, and outlines some of the means used. The policy states:

Procurement in IPF operations supports Borrowers to achieve value for money with integrity in delivering sustainable development. To achieve this vision, the Bank seeks assurance from Borrowers that acceptable procurement arrangements are applied to the financial resources it provides to Borrowers, and supports Borrower countries in enhancing and implementing sound procurement systems and institutions. The Bank may support country capacity building at the level of the project or as part of the country dialogue, using a range of measures-funding, technical support, and handson expanded implementation support (in selected cases) - depending on the specific context of the country, sector, agency, or project. ${ }^{33}$

\footnotetext{
${ }^{26}$ World Bank, Procurement in World Bank Investment Project Financing -- Phase II: The New Procurement Framework, supra note 6, at 11.

${ }^{27} \mathrm{Id}$. at 12 (describing preparatory steps over three-year process).

${ }^{28}$ See, e.g., Peter Trepte, supra note 15 , at 121.

${ }^{29}$ See World Bank, Procurement in World Bank Investment Project Financing -- Phase II: The New Procurement Framework, supra note 6, at 1-2.

${ }^{30}$ World Bank, New World Bank Procurement Framework Approved (July 21, 2015), http://www.worldbank.org/en/news/press-release/2015/07/21/world-bank-procurement-framework.

${ }^{31}$ See, e.g., Sope Williams-Elegbe, supra note 2, at 64-76; Collin Swann \& Sati Harutyunyan, supra note 1.

${ }^{32}$ World Bank, Bank Policy: Procurement in IPF and Other Operational Procurement Matters, Cat. No. OPSVP5.05-POL.144 (Nov. 7, 2017), available at https://policies.worldbank.org/sites/ppf3/PPFDocuments/a3656cb78847417b886f11fa0235216e.pdf.

${ }^{33} I d$. at 2.
} 
As this overview reflects, the core purpose of the procurement guidance -- oversight through management requirements, to ensure the Bank's funds are well spent -- remains unchanged from the earlier era of the Bank's "red" and "green" procurement guidelines. This core goal stems from the Bank's fiduciary obligation to its contributing shareholders, to safeguard the funds entrusted to the Bank for development. Beyond that core goal, however, this new framework looks to new tools, especially capacity-building, to bolster the Bank's oversight, direction and support for procurement in borrower nations.

To frame this new approach, the policy document sets forth key principles used in the Bank's procurement framework. Among other things:

- Although it is tucked away in the Bank's array of guiding principles, "fit for purpose" was arguably the most important guiding principle for Bank officials in reshaping the Bank's oversight of procurement. The Bank's policy document explains that "fit for purpose" applies to both "intended outcomes and . . . procurement arrangements," and it means "determining the most appropriate approach to meet the project development objectives and outcomes, taking into account the context and the risk, value, and complexity of the procurement." By refocusing oversight on the projects and problems that pose the greatest risk, ${ }^{34}$ and by allowing borrowers to use a broader array of procurement tools to accomplish purchasing goals, the principle of "fit for purpose" has played a powerful role in the Bank's new procurement framework.

- The Bank's policy emphasizes "value for money" -- the principle that demands the "effective, efficient, and economic use of resources," with an "evaluation of relevant costs and benefits, along with an assessment of risks," and "non-price attributes and/or life cycle costs." In a procurement framework that stresses value for money, the policy notes, "[p]rice alone may not necessarily represent value for money." 35

- The policy introduces the principle of "economy," a term which might normally be associated with efficiency or even parsimony, but which the Bank's policy applies to a much more diverse array of concepts, such as sustainability, quality, and non-price attributes and/or life-cycle costs. To make sense of this principle, perhaps it is better to see it as a euphemism for change -- as a signal that the Bank is willing to embrace a range of ideas that were irreconcilable, traditionally, with rigid competitions based on low price alone. This new principle of "economy," it should be stressed, goes beyond mere flexibility in procurement method -- it specifically allows borrowers to integrate "sustainability criteria" (which, depending on the national context, could span from "green" procurement to local economic development goals) in "support of the Borrower's own sustainable procurement policy," a new approach that could, in

\footnotetext{
${ }^{34}$ See, e.g., World Bank, Procurement in World Bank Investment Project Financing -- Phase II: The New Procurement Framework, supra note 6, at 7 (focus on high-risk projects).

${ }^{35} I d$. at 3.
} 
effect, allow borrowers to close off competition from abroad as borrowers used purchasing to advance social and political goals closer to home.

- The policy's approach to "integrity" reflects both the promise and the limitations of the Bank's role, and also builds on the Bank's increasing concerns about corruption. ${ }^{36}$ Probably inevitably given the diversity of its stakeholder community, the Bank's approach is more instrumental than normative: its policy does not approach integrity as an end in itself, but rather as a means to ensure the "use of funds, resources, assets, and authority according to the intended purposes and in a manner that is well informed, aligned with the public interest, and aligned with broader principles of good governance." The Bank's approach thus deals with corruption more as an agency problem ${ }^{37}$-- a problem of diverting public resources for personal ends -- than as a symptom of social collapse. As a practical matter, this leaves the Bank standing somewhat apart from the social and political forces gathering against corruption around the world. At the same time, though, this approach allows the Bank to focus on improving the effectiveness of the procurement functions the Bank is nurturing in the developing world, by treating "integrity" more clinically as a means of reducing performance and reputational risks in procurement, and as a means of reducing fiduciary risk in development.

- The Bank's approach to "transparency" in its policy document reflects the Bank's sometimes awkward role as a multilateral development institution caught between politics and practical necessity. Outside the Bank, the "open government" movement treats transparency as an absolute, on the assumption that unflinching openness will transform governance to make it much more responsive to citizens' needs and views. ${ }^{38}$ While the Bank voices support for open government, ${ }^{39}$ its policy treats transparency in a more traditional, instrumental way, as a means of ensuring open communications among an existing network of contractors, officials and stakeholders. The policy calls for transparency to allow an "appropriate review of . . procurement activities, supported by appropriate documentation and disclosure." Transparency, the Bank's policy says, requires that "relevant procurement information be made publicly available to all interested parties, consistently and in a timely manner, through readily accessible and widely available sources at reasonable or no cost" (i.e,, online), that there be "appropriate reporting of procurement activities" (to ensure accountability and effective oversight), and that confidentiality provisions in contracts be used only where justified (to ensure that private imperatives do not overwhelm public goals of transparency). The Bank's policy thus reflects the traditional push-

\footnotetext{
${ }^{36}$ See Sope Williams-Elegbe, supra note 13, at 25-26.

${ }^{37}$ See, e.g., Christopher R. Yukins, A Versatile Prism: Assessing Procurement Law Through the Principal-Agent Model, 40 Pub. Cont. L.J. 63 (2010) (applying agency theory to procurement), available at http://ssrn.com/abstract=1776295.

${ }^{38}$ See, e.g., Open Government Partnership, Open Government Declaration (2011) (discussing principles of open government), https://www.opengovpartnership.org/open-government-declaration.

${ }^{39}$ World Bank, Brief: Open Government (June 18, 2015) (Bank's adherence to principles of open government), https://www.opengovpartnership.org/open-government-declaration.
} 
and-tug over transparency between established stakeholders in the procurement community, and leaves for another day the emerging question of whether all public functions, including procurement, should be fully transparent.

- The Bank's policy's approach to "fairness" is perhaps the most telling. For the Bank, "fairness" is not an agonized normative matter; it is, instead, a rolling effort to manage competing demands among the Bank's many stakeholders. To reconcile those demanding voices, the Bank stresses the need for open competitive procurement -- the traditional answer for "fair" procurement -- and defines fairness largely in terms of process, not norms. "Fairness," for the Bank, refers to affording bidders equal opportunity and treatment, and distributing rights and obligations fairly between borrowers and suppliers, bidders, consultants and contractors. Finally, fairness means "credible mechanisms for addressing procurement-related complaints and providing recourse" (a topic we will return to below, in our discussion of the Bank's procurement complaints mechanism).

The Bank's policy document also touches on more practical concerns in implementing the new procurement framework. The policy discusses "Alternative Procurement Arrangements," under which the Bank may agree to rely upon the procurement rules of another multilateral agency or organization, may agree to allow that other organization to take the lead in implementing and monitoring a project's procurement, or may even rely directly on the procurement rules of a borrower nation's responsible agency. (These "Alternative Procurement Arrangements" are discussed further below, in Part IV.)

Finally, and importantly, the policy confronts conflicts of interest -- which were, ironically, the concerns which launched some of the Bank's earliest procurement reforms in the decades after World War II. ${ }^{40}$ The Bank's policy extends explicitly now to both personal conflicts of interest and what are commonly known as "organizational" conflicts of interest (a conflict of interest a firm may have, for example, in drafting specifications against which that same firm may later bid). ${ }^{41}$ Importantly, the Bank's policy says that "all parties involved in the Procurement Process [shall] not have a conflict of interest, unless such a conflict has been resolved in a manner acceptable to the Bank." 42 This last point is important, because it makes the Bank the ultimate arbiter on issues of conflicts of interest -- a sound approach if the goal is to contain reputational and operational risk from conflicts of interest, but with serious potential issues, practically and structurally. Read strictly, this policy means that any issue of conflict of

\footnotetext{
${ }^{40}$ See Initiating Discussions Paper, supra note 16, at 2.

${ }^{41}$ See, e.g., United Nations Commission on International Trade Law, UNCITRAL Model Law on Public Procurement, Art. 21 (2011), http://www.uncitral.org/pdf/english/texts/procurem/ml-procurement-2011/2011Model-Law-on-Public-Procurement-e.pdf; U.S. Federal Acquisition Regulation, Subpart 9.5, 48 Code of Federal Regulations Subpart 9.5; Whitney Debevoise \& Christopher Yukins, supra note 24 (citing Daniel I. Gordon, Organizational Conflicts of Interest: A Growing Integrity Challenge, 35 Pub. Cont. L.J. 25 (2005); Peter Braun \& Ceren Birespek, Conflicts of Interest in Public Award Procedures: Deloitte Business Advisory NV v. Commission of the European Communities, 2008 Pub. Proc. L. Rev. NA53 (European case law and rules regarding firms' conflicts of interest)).

${ }^{42}$ Bank Policy: Procurement in IPF and Other Operational Procurement Matters, supra note 32, at 4 (emphasis added).
} 
interest would need to be vetted by the Bank, which is a practical impossibility given the vast reach (and overwhelming complexity) of the Bank's work. From a policy perspective, this policy (again, if read strictly) would place the Bank in the role of what is known as a "thirdparty" monitor -- a trusted observer that oversees a threatening situation which may yield conflicts of interest and deviant behavior. ${ }^{43}$ When a third-party monitor fails, that failure can be catastrophic precisely because of others' reliance; making a commitment to review all conflicts of interest thus may be too taxing for the Bank, and may in practice leave its stakeholders with a false sense of security and oversight. We will return to this topic again below, in Part IV.

\section{Key Elements of the World Bank's Procurement Framework}

As noted, although touted as an attempt to simplify procurement oversight at the World Bank, the Procurement Framework was in fact presented as a highly complex suite of interrelated policies and requirements. Key policies were reviewed above; here, we will address important regulations and guidance in the Procurement Framework, focusing on those -specifically, the new Procurement Regulations -- that appear to relate most directly to aid effectiveness goals per the Paris Declaration and the Accra Agenda for Action.

\section{A. The Bank's Procurement Regulations}

The document at the heart of the new Procurement Framework is the Procurement Regulations, which set basic requirements for procurement done by borrowers. As before, the new Procurement Regulations keep the Bank at arm's length from the borrower's procurement contract itself: they explain that the Legal Agreement which frames the borrower's obligation to the Bank stands apart -- as the Bank stands apart -- from the borrower's procurement contract with a vendor. ${ }^{44}$ At the same time, the Procurement Regulations make clear the Bank's unshakeable oversight over the borrower's contracting: the Regulations closely guide the borrower's procurement when the borrower uses Bank financing, and the Regulations explicitly state that even if a borrower's contractor with a vendor is not financed by the Bank but is part of a Bank-financed project, the borrower may adopt other procurement rules and procedures only if "if the Bank is satisfied that ... the rules and procedures will fulfill the Borrower's obligations to carry out the project diligently and efficiently." 45

The Procurement Regulations provide crucial guidance on a number of initiatives which relate directly to aid effectiveness, including Alternative Procurement Arrangements (which would, in principle, allow borrowers to use their own procurement rules), complaints (the Bank's form of bid challenges, and an opportunity for the Bank to exercise oversight over troubled procurements), anti-corruption measures and procurement methods.

\section{Alternative Procurement Arrangements (APAs)}

\footnotetext{
${ }^{43}$ See Christopher R. Yukins, supra note 37 , at 30 \& n. 34.

${ }^{44}$ Procurement Regulations, supra note 14.

${ }^{45}$ Id. II 2.3 .
} 
One of the most conspicuous reforms in the new Procurement Framework was the Bank's endorsement of Alternative Procurement Arrangements (APAs), by which the Bank will allow borrowers to use their own procurement rules if they meet certain criteria. The Bank's embrace of APAs follows an extended period of trial and failure, during which the Bank launched a pilot program to assess borrowers' use of their own national procurement systems for major Bankfinanced projects. (Smaller procurements can be done using National Competitive Bidding (NCB), under the borrower's existing rules.) The "Use of Country Systems" (UCS) initiative largely failed, ${ }^{46}$ probably in part because the Bank expected borrowers, to be eligible, to use procurement systems that mirrored the Bank's own procurement guidelines. ${ }^{47}$

The apparent failure of the "Use of Country Systems" initiative did not, however, end the concept, because allowing borrowers to use their own systems was a core element of internationally recognized aid effectiveness goals (discussed in Part I, above). The Banks' Procurement Framework called for the use of APAs to allow borrowers (or their agencies) to use APAs, subject though to strict assessment requirements. Specifically, the Bank's Procurement Regulations said that the Bank may allow borrowers to use their own procurement rules for specific agencies or procuring entities, subject to the Bank's requirements. ${ }^{48}$

As of this writing, the Bank still has not finalized its assessment requirements for APAs. Draft assessment standards have been developed, based upon the Organization for Economic Cooperation and Development (OECD) Methodology for Assessment Procurement Systems (MAPS), adjusted to include an additional element which assesses procurement operations. The proposed approach also would use data from past procurements, and input from the private sector and civil society organizations (CSOs), to assess whether the nominee agency (or country) is an appropriate candidate for an APA. ${ }^{49}$ More on the assessment methodology is presented in chapters 9 and 10 of this book.

\section{Anti-Corruption Measures}

The Procurement Regulations under the Bank's new framework reflect a mix of old and new anti-corruption strategies. The Bank's anti-corruption measures have, over time, gathered strength as the Bank has come to see corruption as a major obstacle to development. ${ }^{50}$ And as the Bank allows its borrowers to use more sophisticated and riskier methods of procurement,

\footnotetext{
${ }^{46}$ See, e.g., Christopher L. Pallas \& Jonathan Wood, The World Bank's Use of Country Systems for Procurement: A Good Idea Gone Bad?, 27 Dev. Pol. Rev. 215 (2009) (discussing Bank's earlier efforts to allow borrowers to use their country systems for procurement, as part of broader initiatives to improve aid effectiveness).

${ }^{47}$ See Peter Trepte, supra note 15, at 128-31 (discussing the history of the World Bank's "Use of Country Systems" initiative in detail); Sope Williams-Elegbe, supra note 2, at 251-256 ("Use of Country Systems" initiative).

${ }^{48}$ Procurement Regulations, supra note 14, II 2.4 ("At the Borrower's request, the Bank (subject to its policies and rules, and applicable fiduciary and operational requirements), may agree to . . rely on and apply the procurement rules and procedures of an agency or entity of the Borrower.").

${ }^{49}$ See World Bank, A Draft Guide to the APA Assessment: Assessment Methodology to Assess Alternative Procurement Arrangements in Borrower Implementing Agencies for Procurements Financed Under IPF (July 2016), http://pubdocs.worldbank.org/en/634391468437110489/Alternative-Procurement-Arrangements-Guide-tothe-Assessor.pdf.

${ }^{50}$ See Sope Williams-Elegbe, supra note 2, at 178-187 (history of World Bank's efforts against corruption in procurement).
} 
such as competitive dialogue (discussed below), the anti-corruption systems deployed by the Bank's borrowers will become more important.

The Bank's Procurement Regulations embrace an emerging strategy to check corruption: monitoring by independent third parties. Under the new Regulations, when procurement strategies (such as competitive dialogues) present additional risk, ${ }^{51}$ borrowers may retain a "Probity Assurance Provider," an "independent third party that provides specialist probity services for concurrent monitoring of the Procurement Process." ${ }^{\text {. }}$ These monitors may be private firms or may come from civil society organizations (CSOs). ${ }^{53}$

The Probity Assurance Providers may work closely with Bank staff who provide "HandsOn Expanded Implementation Support" (HEIS) when borrowers have urgent capacity constraints. $^{54}$ The HEIS assistance is itself arguably an anti-corruption device, for it allows Bank officials to be involved directly in drafting procurement documents, assessing proposals, observing dialogues and negotiations, and drafting evaluations and award documentation -- thus providing both capacity support and monitoring with experienced Bank staff. Although Bank officials providing HEIS assistance are not to usurp the key decision making to be done by borrowers, such as the procurement award decision, the HEIS assistance can assist borrowers "to deliver effective procurement processes beyond the normal implementation support" the Bank would provide. $^{55}$

Otherwise, the Bank's anti-corruption measures were generally strengthened but not radically changed by the 2016 reforms. ${ }^{56}$ Fraud and corruption concerns were given special prominence in the new complaints procedures (see below), so that those will gain special attention from the Bank and the borrower as they arise. ${ }^{57}$ The conflict-of-interest provisions in the new Procurement Regulations ${ }^{58}$ for example, generally track those of the prior Procurement Guidelines. ${ }^{59}$ As was noted above in the discussion of the Bank's guiding principles, the Bank's approach to integrity remains instrumental, still largely removed from more normative questions

\footnotetext{
${ }^{51}$ When preparing a Project Procurement Strategy for Development (PPSD) (the precursor to a formal procurement plan), http://pubdocs.worldbank.org/en/847531467334322069/PPSD-Long-Form.pdf, borrowers are expected to assess whether "any proposed additional oversight (e.g. probity assurance)" is required, such as "due to risk in the proposed procurement arrangements (such as use of negotiations, competitive dialogue)." World Bank, Project Procurement Strategy for Development: Short Form Detailed Guide, at 43 (July 2016), https://wbnpf.procurementinet.org/sites/all/themes/npf/misc/documents/PPSD-Short-Form-Final-June-30.pdf; see also Sope Williams-Elegbe, supra note 2, at 83-84 (describing PPSD).

${ }^{5}$ See Procurement Regulations, supra note 14.

${ }^{53}$ For an interview describing CSOs' efforts to monitor procurement in various projects around the world, see Interview with Christopher Yukins and Donal O'Leary, Sabine Engelhard and Lars Jeurling of the Partnership for Transparency Fund (PTF) (2018), https://www.youtube.com/watch?v=-1NnM-AH67s.

${ }^{54}$ World Bank, Bank Guidance: Procurement Hands-on Expanded Implementation Support, Cat. No. OPS5.05GUID.167, § III.A.7 (Aug. 3, 2016), https://policies.worldbank.org/sites/ppf3/PPFDocuments/3c801309d23748bd932e756bf58468ac.pdf.

${ }^{55}$ Id. $\S$ III.A.

${ }^{56}$ See Sope Williams-Elegbe, supra note 2, at 187-215 (detailed review of anti-corruption measures in Bankfinanced procurement).

${ }_{58}^{5}$ See Procurement Regulations, supra note 14, II 3.31.

${ }^{58}$ See id. $\llbracket$ II 3.14.

${ }^{59}$ See Procurement Guidelines, supra note 21, II 1.6 et seq.
} 
such as public censure. ${ }^{60}$ Furthermore, the anti-corruption sanctions that the Bank undertakes are focused on specific (and past) acts of contractor misconduct, ${ }^{61}$ and not more broadly on ensuring that performance and reputational risks are reduced in Bank projects on an ongoing basis. ${ }^{62}$

\section{Focusing Oversight on Procurement Risk}

A cornerstone to the Bank's new Procurement Framework -- the logical extension of the "fit for purpose" principle discussed above -- is to focus the Bank's oversight and reviews ${ }^{63}$ on high-risk and/or high-value procurements. ${ }^{64}$ The process for triggering a review is complex:

- Procurement risk is assessed independently, based on factors such as perceived capacity in the borrower agency, market conditions and the procurement approach to be used. $^{65}$

- That perceived risk ("low" to "high") is then assessed against a sliding dollar scale; high-risk projects, for example, will trigger a review at lower dollar value. ${ }^{66}$

Thus, the procurement risk is very much assessed from the Bank's perspective -- the reviews focus on addressing the Bank's fiduciary obligations and the need to mitigate risk in the procurement itself, not on the performance risks that the project (or its beneficiaries) may face.

The Bank's Procurement Procedure appears to confirm that focus, because it mandates reviews when certain procedures which the Bank considers inherently risky (such as competitive dialogue $)^{67}$ are used. $^{68}$ These risks are not necessarily linked to the borrower's performance risk; instead, these are risks tied to a potential failure of the procurement itself, i.e., a failure to purchase best value.

\footnotetext{
${ }^{60}$ See Sope Williams-Elegbe, supra note 2, at 215-216.

${ }^{61}$ See, e.g., Procurement Regulations, supra note 14, Annex IV, II 2.2.

${ }^{62}$ See, e.g., Christopher R. Yukins, Rethinking the World Bank's Sanctions System, 55 Gov. Contractor II 355 (November 21, 2013), available at https://papers.ssrn.com/sol3/papers.cfm?abstract_id=2357691; Pascale Helene Dubois, Paul Ezzeddin \& Collin David Swan, Suspension and Debarment on the International Stage: Experiences in the World Bank's Sanctions System, 2016 Pub. Proc. L. Rev. 61; Johannes S. Schnitzer \& Christopher R. Yukins, Combating Corruption in Procurement, in UNOPS, Future Proofing Procurement 26 (2016) (discussing how different anti-corruption strategies address different classes of risk, reputational versus performance), http://www.bhrinlaw.org/documents/2015-asr-supplement.pdf. For a broader discussion of debarment systems used around the globe, see Sope Williams-Elegbe, Fighting Corruption in Public Procurement: A Comparative Analysis of Disqualification or Debarment Measures (Hart Publishing 2012).

${ }^{63}$ See, e.g., Sope Williams-Elegbe, supra note 2, at 190-192.

${ }^{64}$ See, e.g., Procurement Regulations, supra note 14, \[ 3.5.

${ }^{65}$ World Bank, Project Procurement Strategy for Development -- Long Form Detailed Guidance, sections IV-V (July 2016), http://pubdocs.worldbank.org/en/847531467334322069/PPSD-Long-Form.pdf

${ }^{66}$ See, e.g., World Bank, Bank Procedure: Procurement in IPF and Other Operational Procurement Matters, Cat. No. OPS5.05-PROC.136, Annex I (Nov. 7, 2017),

https://policies.worldbank.org/sites/ppf3/PPFDocuments/17dbb39aa89d40b18f01060d1ae1c383.pdf; Sope

Williams-Elegbe, supra note 2, at 191.

${ }^{67}$ Project Procurement Strategy for Development -- Long Form Detailed Guidance, supra note 65, at 17.

${ }^{68}$ Bank Procedure, supra note 66, at 25-26; Procurement Regulations, supra note 14, Annex II.3. 


\section{Procurement-Related Complaints}

The Bank's new Procurement Framework included important reforms to the Bank's procedures for handling procurement-related complaints. ${ }^{69}$ Under the reformed process, procurement-related complaints are to be submitted to the borrower in a timely manner, and the borrower is to track and address those complaints. The borrower is to resolve the complaints under either the procedures set forth in Annex III to the Procurement Regulations (for procurements covered by Standard Procurement Documents), under national complaints procedures agreed upon by the Bank (for national competitive bidding (NCB)), or, for Alternative Procurement Arrangements (discussed above), under complaints procedures agreed upon by the Bank. ${ }^{70}$ Where the procurement is subject to prior review, the Bank is to consider the complaint and timely consider the action proposed by the borrower. ${ }^{71}$

The World Bank's complaints procedure operates, in a very loose sense, like "bid protest" or "remedies" procedures in national systems: the complaints procedure allows bidders to complain to the government running the procurement of failures in contract formation, and (in some cases) the Bank will play a monitoring role. Complaints (bid challenges) are sometimes viewed as anti-corruption devices, but given the institutional constraints on any complaints body -- they typically lack investigative authority or police powers, and have a specialized focus on procurement -- these reviewing bodies are probably better viewed as guardians of the procurement process. Many nations now have bid challenge systems in place to supervise their own procurement systems, ${ }^{72}$ and the Bank's complaints procedure builds on those institutions while providing, to a limited extent, another layer of review at the Bank.

In framing reforms to the complaints procedure, the Bank noted that many in the private sector had requested much stronger Bank involvement when complaints arose regarding Bankfinanced procurements; the private sector argued that a more robust complaints process would build private confidence in Bank-financed procurement, which in turn would encourage stronger competition. ${ }^{73}$ To address these concerns, the Bank agreed to dedicate senior staff to advise on

\footnotetext{
${ }^{69}$ See Procurement Regulations, supra note 14,II II 3.26 to 3.31 \& Annex III; World Bank, ProcurementProcurement-Related Complaints: How to Complain (2d ed. January 2017) (discussing complaints arising in connection with contracts where the Bank's Standard Procurement Documents (SPDs) apply); Sope WilliamsElegbe, supra note 2, at 284-291 (noting improvements from 2011 Procurement Guidelines to the 2016 Procurement Framework's complaints process).

${ }^{70}$ Procurement Regulations, supra note 9, TाI 3.28 \& 3.30; World Bank, Webinar: New Procurement Framework: Procurement-Related Complaints 12, http://pubdocs.worldbank.org/en/690521503326539557/Webinar-HandlingProcurement-Related-Complaints.pdf.

${ }^{71}$ Id. Annex III, II 3.9.

${ }^{72}$ Complaints systems are required, for example, by Article 9 of the United Nations Convention Against Corruption, https://www.unodc.org/documents/treaties/UNCAC/Publications/Convention/08-50026_E.pdf, and by Article XVIII of the World Trade Organization's revised Government Procurement Agreement, https://www.wto.org/english/docs_e/legal_e/rev-gpr-94_01_e.htm. See generally Daniel I. Gordon, Constructing a Bid Protest Process: Choices Every Procurement Challenge System Must Make, 35 Pub. Cont. L.J. 427 (2006), available at https://ssrn.com/abstract $=892781$.

${ }^{73}$ See World Bank, Procurement in World Bank Investment Project Financing -- Phase II: The New Procurement Framework, supra note 6, at 5-6.
} 
and expedite procurement-related complaints. ${ }^{74}$ Under the new Procurement Regulations, all complaints regarding an International Project Finance (IPF) operation must be reported to the Bank (including for national procurements and procurements done using "Alternative Procurement Arrangements" (APAs)). Debriefings to bidders regarding the bases for award are required, and standstill periods (to allow for a debriefing and, if necessary, a complaint) are now required under the Bank's standard selection documents. Complaints regarding contract awards are monitored by the Bank, and, for post-award disputes regarding contract performance, the Bank will facilitate dispute resolution.

The new complaints process still appears to be a work in progress, and the normal remedies afforded by a bid challenge system generally are not available in the Bank's own process. ${ }^{75}$ While the Procurement Framework puts the basic elements of a bid challenge system in place (e.g., borrowers' debriefings are called for, interested parties are clearly defined, a standstill period is required, "business standard" deadlines are set, and there is an established process), the new framework, out of the Bank's normal institutional deference, will leave the review largely to the borrower nation. ${ }^{76}$ There is no regular or transparent means of tracking complaints brought to the Bank, and there are no published decisions from the Bank to shed light on how the law is developing, or how recurring issues will be addressed. To the extent the complaints process remains immature and incomplete, sophisticated bidders frustrated with a Bank procurement may turn first to the traditional alternative -- private requests for intercession by the Bank.

The gaps in the Bank's complaints process may be felt most keenly on those projects that now will fall outside the Bank's close review, as the Bank focuses its oversight and resources on its highest-risk, highest-value projects (see above). The projects newly pushed to the periphery probably will still be just as important to the agencies involved, and just as strategically vital to the vendors competing for that work; the agencies and vendors, however, will no longer have the same benefit of Bank oversight. This makes it more likely that there will a sort of centrifugal movement, away from the Bank's central control, as vendors and other stakeholders seek out solutions for the problems that inevitably emerge.

One obvious place to go will be the bid challenge forums in the borrowing nations. The Bank's Procurement Framework almost predicts that -- it leaves the complaints process in the hands of the borrower nations. But the Bank's Procurement Framework has no special place for building capacity in the bid challenge institutions emerging around the world, and the Bank's own still incomplete complaints procedures say much about the Bank's own apparent ambivalence about bid challenges.

If vendors confronting corruption on Bank-financed projects cannot resolve problems in the borrower nations' bid remedies systems, they may seek help from the rapidly growing network of anti-corruption agencies called for by various international anti-corruption

\footnotetext{
${ }^{74} I d$. at 6 .

${ }^{75}$ See, e.g., Sope Williams-Elegbe, supra note 2, at 291 ("it is a misnomer to talk of remedies in the traditional sense in the context of bidders on a Bank-funded procurement").

${ }^{76}$ See, e.g., Peter Trepte, supra 15, at 149.
} 
instruments, ${ }_{79}^{77}$ and bolstered by new anti-corruption laws, such as those in the United Kingdom ${ }^{78}$ and France. ${ }^{79}$

If vendors encounter more prosaic problems -- if they face not corruption, but simple bureaucratic collapse -- and they cannot rely on borrower nations' bid remedies systems, vendors may possibly turn to relief under bilateral investment treaties. Under certain circumstances, those treaties allow for investor-state disputes (which may be administered, ironically, through one of the World Bank's own institutions, the International Centre for the Settlement of Investment Disputes (ICSID)), and those types of disputes may emerge as an alternative remedy for investors frustrated with World Bank-financed procurements that now fall outside the narrowed band of review by the Bank. ${ }^{80}$

While it is difficult to predict what pathway frustrated vendors may take, what is clear is that the Bank's narrowed oversight, including its highly deferential complaints process, may have collateral effects which cannot be resolved simply by building capacity in borrower nations. Problems emerge in even more mature procurement systems (there are thousands of bid challenges brought in North America and Europe every year, for example), and the Bank's new, narrower approach to oversight is likely to have spillover effects as contracting problems go unresolved in the normal course. The Bank's more focused approach to oversight allows the Bank to focus resources on its points of highest risk, and in effect leaves more authority to borrower nations to police other projects -- an outcome that seems consonant with the Paris Declaration and the Accra Agenda for Action, but in practice could have a negative impact on Bank-funded projects..

\section{Sustainable Procurement}

The Bank's Procurement Framework includes new provisions allowing for sustainable procurement strategies, ${ }^{81}$ such as the special procedures outlined in Annex VII to the Procurement Regulations. Sustainability, in the Bank's view, extends to economic, environmental and social factors, and the Bank "encourages Borrowers to actively consider and apply sustainable procurement, where appropriate." 82 Although the Bank's new framework allows borrowers to incorporate sustainability goals in procurement in an approach reminiscent

\footnotetext{
${ }^{77}$ See generally Sofia Wickberg, Transparency International, Best Practices for Anti-Corruption Commissions (2013), available at https://www.transparency.org/files/content/corruptionqas/Best_practices_for_anticorruption_commissions_2.pdf.

${ }^{78}$ UK Bribery Act 2010, available at https://www.legislation.gov.uk/ukpga/2010/23/contents.

${ }^{79}$ Loi No. 2016-1691 du 9 décembre 2016 relative à la transparence, à la lutte contre la corruption et à la modernisation de la vie économique (commonly known as the "Sapin II" law), available at https://www.legifrance.gouv.fr/eli/loi/2016/12/9/2016-1691/jo/texte.

${ }^{80}$ See, e.g., Yarik Kryvoi, Bribery, Corruption, and Fraud in Investor-State Disputes: How Should Tribunals Approach Economic Crimes?, Aug. 10, 2018, http://arbitrationblog.kluwerarbitration.com/2018/08/10/briberyinvestor-state/.

${ }^{81}$ See, e.g., World Bank, Sustainable Procurement: An Introduction for Practitioners to Sustainable Procurement in World Bank IPF Projects (Nov. 2016), http://pubdocs.worldbank.org/en/788731479395390605/SustainableProcurement-Guidance-FINAL.pdf; Sope-Williams Elegbe, supra note 2, at 155-157; Peter Trepte, supra note 15, at 133-134.

${ }^{82}$ Procurement Regulations, supra note 14, II 5.12 \& Annex VII, II 2.3.
} 
of the European Union's, ${ }^{83}$ the Bank still considers sustainability a procurement risk which will trigger a prior review. ${ }^{84}$

The Bank's cautious approach to sustainability reflects a narrow path the Bank must tread. There is broad support internationally for many of the goals of sustainability, such as addressing climate change and improving socio-economic conditions. At the same time, however, "sustainability" remains only loosely defined, ${ }^{85}$ and sustainability goals can be used by procuring agencies for less lofty purposes, such as favoring advanced firms uniquely able to meet emerging sustainability goals. ${ }^{86}$ The Bank's ambivalence is reflected in Annex VII to the Bank's Procurement Regulations, which allow sustainability goals but stress that "sustainable procurement requirements should be based on evidence (i.e., with supporting data), and on existing social-label criteria, eco-label criteria, or information collected from stakeholders in industry, civil society, and international development agencies." ${ }^{87}$ By demanding a documented, rational basis for sustainability goals, one informed by best practices and standards, the Bank apparently hopes to limit the risks of discrimination and corruption that sustainability might otherwise present.

\section{New Procurement Methods -- Including Competitive Dialogue}

While the Bank's Procurement Framework endorsed a number of innovations in procurement methods, from a technical standpoint perhaps the most important was the Bank's embrace of competitive dialogue. Other methods were already gaining traction -- framework agreements were allowed under the prior Procurement Guidelines and electronic reverse auctions were already being addressed in practice by the Bank ${ }^{88}$-- but the World Bank's decision to accept competitive dialogue as a procurement method was a marked change, as many Bank officials had long been quite hostile to competitive dialogue and the corruption risks it brings. Although the new Procurement Regulations allow other new procurement methods as well, ${ }^{89}$ our focus here is on competitive dialogue both because it sheds light on what shaped the World

\footnotetext{
${ }^{83}$ See Peter Trepte, supra note 15, at 133-34.

${ }^{84}$ See, e.g., Bank Procedure, supra note 66, at 21 (World Bank Team Leader is to prepare "a memorandum . . . seeking . . . approval to include Borrower's sustainability requirements (i.e., the application of social and economic criteria) in World Bank-financed procurement"); id. Annex I, II 2.2 ("irrespective of the contract value, the following procurement activities are subject to the Bank's procurement prior review ... (c) sustainable procurement").

${ }^{85}$ See, e.g., Jeff Gutman, Book Review: Public Procurement and Multilateral Development Banks: Law, Practice and Problems, 2018 Pub. Proc. L. Rev. 96, 99.

${ }^{86}$ See, e.g., Rita Roos, Deutsche Gesellschaft für Internationale Zusammenarbeit (GIZ), Sustainable Public Procurement in LICs[Low-Income Countries], at vii (2013) ("There is also the perceived risk of SPP [Sustainable Public Procurement] creating unfair competitive advantage for few (often large, international) firms able to comply with SPP standards."),

https://consultations.worldbank.org/Data/hub/files/meetings/Procurement_Policies/SPP_in_LICs.pdf.

${ }^{87}$ Procurement Regulations, supra note 14, Annex VII, II 2.4.

${ }^{88}$ See, e.g., World Bank, e-Reverse Auction Guidelines for MDB Financed Procurement (Dec. 2005), https://openknowledge.worldbank.org/bitstream/handle/10986/19058/883170WP0eReve00Box385191B00PUBLIC 0 .pdf? sequence $=1 \&$ is Allowed $=\mathrm{y}$.

${ }^{89}$ See, e.g., Peter Trepte, supra note 15, at 134-38; Sope Williams-Elegbe, supra note 2, at 131-42.
} 
Bank's new Procurement Framework, and it helps predict the role the Bank's new framework will play in international development in the coming years.

The Bank's acceptance of competitive dialogue followed parallel developments around the world, such as the European Union's embrace of competitive dialogue (and competitive procedure with negotiation, its close cousin) in the European procurement directives, ${ }^{90}$ the inclusion of a form of competitive dialogue in the 2011 rewrite of the UN Commission on International Trade Law (UNCITRAL) model procurement law, ${ }^{91}$ and the shift of much of U.S. federal contracting to a more liberal form of competitive dialogue, called "competitive negotiations," under the Federal Acquisition Regulation. ${ }^{92}$

All these methods call for competitive multilateral negotiations, in which the purchasing agency enters into a "dialogue" with each offeror, either in writing or orally, through which each offeror can present a unique solution to the purchasing agency's stated requirements. This is a dramatic change from classic open tendering (called "sealed bidding" in the United States federal system), ${ }^{93}$ which proceeds from the assumption that the government customer can define its needs with precision and then award (generally speaking) based on low price.

The shift internationally from open tendering (traditionally, the default method) to competitive dialogue reflects, in many ways, passage over a technological divide. In a more primitive age, it made sense for a government to specify a uniform solution for its requirements, and then to award a contract for that uniform solution to the lowest bidder. Rapidly advancing technology has changed that calculation, however, and competitive dialogue allows procuring agencies to choose among technologically advanced solutions -- solutions which may be idiosyncratic precisely because they are technologically advanced, and so do not lend themselves to low-price bidding against a defined set of requirements. Competitive dialogue also gives government customers a "window" into emerging technologies, because vendors engaged in a competitive dialogue with a government customer will be more willing to disclose their advanced solutions in a closed environment of private exchanges. Finally, because competitive dialogue (unlike traditional tendering) allows the government to choose among a more diverse array of potential solutions, it is more likely that the chosen solution -- the awardee -- will better "fit" the government's actual requirements.

In economic terms, competitive dialogue thus helps mitigate the principal-agent issues (discussed above) that normally burden public procurement. By allowing the public buyer to

\footnotetext{
${ }^{90}$ EU Procurement Directive 2014/24/EU, Arts. 29-30, available at https://eur-lex.europa.eu/legalcontent/EN/ALL/?uri=CELEX\%3A32014L0024; see also Office of Government Commerce, UK Government, Competitive Dialogue in 2008 (2008) (guidance on use of competitive dialogue and other procedures), available at http://webarchive.nationalarchives.gov.uk/20130102211752/http://www.hmtreasury.gov.uk/d/competitive_dialogue_procedure.pdf.

${ }^{91}$ UNCITRAL Model Law on Public Procurement, supra note 41, Art. 49 (request for proposals with dialogue).

${ }^{92}$ See FAR Part 15, 48 Code of Federal Regulations Part 15; Christopher R. Yukins, The U.S. Federal Procurement System: An Introduction, 2017 Upphandlingsrättslig Tidskript 69, 81-84, available at https://www.urt.cc/?q=node/187; https://ssrn.com/abstract=3063559.

${ }^{93}$ See FAR Part 14, 48 Code of Fed. Regs. Part 14. See generally John Cibinic, Jr. Ralph C. Nash, Jr. Christopher R. Yukins, Formation of Government Contracts, ch. 4 (Aspen (Wolters Kluwer Legal) $4^{\text {th }}$ ed. 2011).
} 
engage directly with many diverse solutions in the marketplace through multilateral negotiations, competitive dialogue can mute the distorting self-interest of the intermediary, the contracting official, who traditionally might default to a uniform, inflexible solution to allow award to a low bidder. Competitive dialogue allows for a more nuanced balancing of price and quality, and allows buyers to access diverse emerging technologies, and thus may reduce performance risk for the buyer. (Conversely, the traditional strong preference for open tendering could retard development, by forcing public buyers back onto simpler, uniform solutions.)

At the same time, however, competitive dialogue almost certainly increases reputational risk, for both the buyer and the financier (here the World Bank), precisely because it is a dialogue. The exchanges between offerors and the government customer typically take place privately, and open an array of opportunities for corruption. World Bank policymakers know that, and though many officials argued that they opposed competitive dialogue because it is too complex for young procurement systems, in fact that reputational risk may have been a major reason for the Bank's longstanding opposition to competitive dialogue.

The Bank's embrace of competitive dialogue thus tells us much. The fact that the Bank resisted competitive dialogue for so long gives us some insight into the Bank's keen sensitivity to reputational risk; that is natural, given the Bank's exposure to criticism (often from those hostile to its philanthropic mission) and the deeply corrosive effect that corruption (a risk with any competitive dialogue) can have on the Bank. At the same time, the fact that the Bank did eventually embrace competitive dialogue because the Bank realized it was falling out of step with emerging best practices, and the fact that the Bank's change of heart has helped persuade others to embrace competitive dialogue as well, confirmed the important role the Bank plays in defining and modeling best practices in procurement.

\section{Capacity Development}

The Bank's roles in defining best practices and driving reform in procurement go handin-hand with the Bank's commitment to building capacity. In procurement, building capacity means helping governments and societies do procurement better, to ensure that those governments can buy the best possible goods and services for the people they serve. ${ }^{94}$ Capacitybuilding can mean training and counseling government personnel, and it can mean building understanding in the private sector as well, among contractors and their personnel, and in the institutions and professions that support the procurement system. Recognizing all this, the World Bank and other multilateral development institutions have long supported capacitybuilding efforts in the developing world, and strengthening capacity is a building block to effective aid.

\footnotetext{
${ }^{94}$ See, e.g., UNDP, Public Procurement Capacity Development Guide (2010), available at http://www.undp.org/content/dam/aplaws/publication/en/publications/capacity-development/undp-procurementcapacity-assessment-users-guide/Procurement\%20Capacity\%20Assessment\%20Guide.pdf; Sope Williams-Elegbe, Beyond UNCITRAL: The Challenges of Procurement Reform Implementation in Africa, 2014 Stellenbosch L. Rev. 209, 210-15; Sope Williams-Elegbe, supra note 2, at 249-50; Christopher Yukins \& Ruairi Macdonald, Capacity Building in Public Procurement: Burma/Myanmar-A Case Study, 44 Pub. Cont. L.J. 749 (2015).
} 
In a series of declarations and commitments, ${ }^{95}$ the international development community has recognized the importance of capacity-building to successful procurement policy. One of the most comprehensive plans for building capacity was published by the Organisation for Economic Co-operation and Development (OECD) in 2015, in a model built around a "steering committee" of stakeholders brought together to build capacity in procurement:

\section{Provide leadership: Creating the steering committee}

The first step is to create the steering committee, to include all relevant stakeholders to co-ordinate all activities as well as the strategy.

\section{Identify the issues: Assessing the public procurement workforce}

This diagnostic step is necessary to assess the current needs in terms of institution capacity, staff competency and the education system.

\section{Establish perspective: Identifying the goals}

The steering committee should identify and prioritise the goals in terms of people and institutions, professionalising the procurement function and jobs.

\section{Seek solutions: Finding the appropriate training solutions}

The strategy recommends different types of training in terms of duration, institutions and format, depending on the needs.

\section{Design the programme: Drafting the strategic action plan}

The strategic action plan should include scheduled objectives, actions, and timeframe, while identifying the beneficiaries of the actions.

\section{Include training: Drafting the training action plan}

The training action plan will depend on the needs, and should focus on training solutions for designated individuals and institutions.

\section{Remember resources: Financing the strategy}

The financing is a key step for the success of the implementation of the strategy. The steering committee should consider different options and models from internal and external donors.

\section{Monitor the results: Learning and adapting}

The last step is important to identify best practices or unsuccessful solutions with constant adaptation of the trainings. ${ }^{96}$

\footnotetext{
${ }^{5}$ See, e.g., OECD, Recommendation of the Council on Public Procurement, Art. IX (2015), available at http://www.oecd.org/gov/public-procurement/recommendation/OECD-Recommendation-on-PublicProcurement.pdf.

${ }^{96}$ OECD, Roadmap: How To Elaborate a Procurement Capacity Strategy 6 (2015), available at http://www.oecd.org/governance/ethics/Roadmap-Procurement-Capacity-Strategy.pdf.

Janos Bertok, Head of the Public Sector Integrity Division, and Paulo Magina, Head of the Public Procurement Unit at the OECD, played important roles in preparing the OECD Roadmap, with Kenza Khachani, an OECD policy analyst.
} 
The OECD Roadmap explained how building capacity would reinforce each key pillar in a sound public procurement system, including (1) simple and clear rules that ensure access to procurement opportunities; (2) effective institutions to plan and manage public contracts; (3) appropriate tools for electronic procurement; (4) suitable, skilled human resources -procurement officials, in other words; and (5) competent contract management. ${ }^{97}$ The Roadmap reflects the "top-down" approach to capacity-building generally favored by large institutions engaged in procurement: a government-focused, centralized effort to identify and instill key training goals in procurement, typically built around an established rules system. ${ }^{98}$

At least in principle this traditional approach to capacity-building in procurement, which works best from an established base of rules, put the World Bank in a quandary: having endorsed a broadening use of borrower nation's procurement systems, and having recognized the need to support capacity-building under the new procurement framework, ${ }^{99}$ which set of rules would form the foundation of the Bank's capacity-building -- the Bank's new procurement regulations or the borrower nations' own rules? The answer appears to be a "fit for purpose" approach, which focuses first on a borrower nation's own capacity needs and not on training in the World Bank's procurement regime. The World Bank's Directive -- Procurement in IPF and Other Operational Procurement Matters describes how support to borrowers for their procurement capacity-building will be structured, through direct support at the project level or as part of a country-wide initiative. ${ }^{100}$ With regard to its own procurement framework, the World Bank has posted various learning resources on its website, ${ }^{101}$ though not as part of a fixed curriculum, and the Bank has co-sponsored a "MOOC" (a "massive open online class") to provide low- or no-cost online training in the Bank's new procurement framework. ${ }^{102}$

\footnotetext{
${ }^{97} I d$. at 5.

${ }^{98}$ See , e.g., UNDP, supra note 94. The OECD Roadmap notably cited the U.S. Defense Acquisition University (DAU), probably one of the world's largest institutions dedicated to procurement training. OECD, supra note 96, at 96. In federal fiscal year 2017, for example, DAU received approximately US \$139 million in funding to train the defense acquisition workforce. U.S. Office of the Undersecretary of Defense (Comptroller), Chief Financial Officer, Operation and Maintenance Overview Fiscal Year 2019 Budget Estimates, at 147 (Mar. 2018), available at https://comptroller.defense.gov/Portals/45/Documents/defbudget/fy2019/fy2019_OM_Overview.pdf. The training at DAU is focused on ensuring that the thousands of members of the Defense Department's acquisition workforce are trained in the U.S. government's complex web of policies, rules and procedures for acquisition. See, e.g., DAU, 2016-2019 Strategic Plan (2016), available at https://www.dau.mil/about/PublishingImages/Special\%20Interest\%20Areas/StrategicPlan.pdf.

${ }^{99}$ See, e.g., World Bank, Procurement In World Bank Investment Project Finance Phase I: A Proposed New Framework 25 (rev. Oct. 18, 2013) ("strengthening client institutional capability is a central theme of the proposed new framework and capacity building efforts and procurement reforms would form part of the Bank's larger country engagement, the resources for which would be part of the country dialogue and priorities"), available at http://siteresources.worldbank.org/PROCUREMENT/Resources/ProcurementProposedNewFrameworkOctober2013 Final.pdf.

${ }^{100}$ World Bank, Directive -- Procurement in IPF and Other Operational Procurement Matters 6 (Nov. 1, 2017), available at https://policies.worldbank.org/sites/ppf3/PPFDocuments/95d59b3ec7a84a8782207aa0609dea0d.pdf.

${ }^{101}$ E.g., World Bank, e-Learning Platforms, https://wbnpf.procurementinet.org/e-learning-programs.

${ }^{102}$ World Bank et al., Certificate Program in Public Procurement (MOOC), available at https://www.procurementlearning.org/certificate-program-public-procurement-cppp/.
} 
What the Bank's new initiatives did not address, however, is probably the next historical phase in capacity-building, as the educational institutions in borrower nations mature and can provide procurement training in a private marketplace. In that "bottom-up" environment, individuals make career decisions to advance in procurement, whether (for example) as contracting officials, vendor employees, investigators, lawyers, auditors or accountants. To advance their careers, those individuals will seek out education in a private educational marketplace (which may still include public institutions, such as universities) that responds to that demand. The private marketplace for capacity-building imposes far higher transaction costs (individuals must seek out, assess and purchase the training, and those offering training must market and sell continuously, in a rapidly evolving environment with generally loosely defined standards). But those offering training in that "bottom-up" private marketplace can adapt much more readily to change, and the professionals who emerge from that "bottom-up" capacitybuilding system are deeply invested in their training and committed to the procurement field -and that, in turn, may mean that those individuals are more likely to resist corruption and embrace reform.

\section{Possible Responses to the Bank's Shifting Role as a Monitor}

By focusing the Bank's oversight on the points of greatest risk in the Bank's loan portfolio, the World Bank's procurement reforms are logical and efficient but open new areas of potential conflict.

The chief risk involves the Bank's oversight itself. By design, the Bank has positioned itself as a third-party monitor in its projects around the world; by approving important milestones in those projects through the "no-objection" process, it serves as a monitor for its many stakeholders, including both its shareholders and its borrowers. The economic literature teaches us, however, that a third-party monitor is uniquely trusted -- other parties may rely too heavily, if anything, on the impartial monitor -- and this can be highly disruptive if the third-party monitor fails in its role. ${ }^{103}$ To avoid this type of chaotic collapse, it will be important for the Bank to be transparent, and to clearly explain the new boundaries of its monitoring role.

A good example of this problem is the Bank's new complaints process, for monitoring bid challenges in borrower countries. As the discussion above reflects, the Bank's involvement remains very much that of a third-party monitor, and unlike corruption (which may elicit a debarment from the Bank directly through the sanctions system), a failure of procurement process will be monitored, but not necessarily remedied, through the expanded complaints process at the Bank. This uncertainty regarding the Bank's oversight may engender friction with both vendors and borrowers, as each set of stakeholders jockeys for the Bank's intercession or acquiescence. While that dynamic may bolster Bank officials' tactical leverage in any given

\footnotetext{
${ }^{103}$ Christopher R. Yukins, supra note 37, at 70-71. For other perspectives on agency theory in public procurement, see Agnieszka Chrisidu-Budnikagnieszka \& Justyna Przedańskajustyna, The Agency Theory Approach to the Public Procurement System, 7 Wroclaw Rev. L. Admin. \& Econs. 154 (2018), available at https://doi.org/10.1515/wrlae2015-0059; Omar Azfar, Disrupting Corruption, in Performance Accountability and Combating Corruption, ch. 8 (Anwar Shah, ed., 2007), available at http://siteresources.worldbank.org/PSGLP/Resources/PerformanceAccountabilityandCombatingCorruption.pdf.
} 
procurement, the uncertainty of the new structure also may, over the long term, erode the Bank's perceived authority as a monitor.

Resolving this problem -- making clear the boundaries of the Bank's oversight -- will be made more complicated by the Bank's likely shift over the coming decades to relying more heavily on borrower country procurement systems. The Bank's new framework, as noted, will take a highly variable approach to that shift to country systems, and it is likely that some borrowers' robust procurement systems will be approved long before others', and the approved systems will garner less oversight from the Bank. In practice, this may mean that the Bank's direct oversight will grow more uneven over the coming years, potentially varying from country to country or even from agency to agency within the same country. To ease this problem, it will be important for the Bank to be highly transparent regarding the scope, and practical reach, of its oversight of any given project.

\section{Conclusion: The World Bank's Procurement Framework and Aid Effectiveness}

As the discussion above reflects, the World Bank's new Procurement Framework was, in the words of one highly respected expert, more "evolutionary" than "revolutionary."104 Reform had been a near-constant in World Bank procurement over many decades, and as one former World Bank procurement official noted, the Bank, "to address its client countries concerns and to improve the overall effectiveness of its actions," had long "attempted to develop a procurement policy beyond its narrow fiduciary responsibility." 105 The question, then, is how the latest iteration of reform, the Bank's Procurement Framework, measures against international goals for aid-effectiveness.

Even before the Paris Declaration and the Accra Agenda for Action, the Bank's procurement policies sought to "establish modern and simplified procurement rules, to harmonise public procurement rules among donors and to build procurement capacity in Bank's client countries." 106 Drawn against that history of reform, the Paris Declaration and the Accra Agenda for Action marked important inflection points in development policy internationally, ${ }^{107}$ and they provide useful benchmarks to assess the Bank's most recent procurement reforms, in terms of aid-effectiveness.

In keeping with the Paris Declaration and the Accra Agenda for Action, the World Bank's recent procurement reforms clearly set out to strengthen borrower nations' operational capacity in procurement. The Bank's capacity-building efforts, as noted, focus first on building capacity under borrowers' own systems, and not merely in the Bank's procurement regime. The Bank's reforms also respect borrowers' leadership in their own development. Borrowers assess their own projects risks, and even when Bank personnel are called in to provide direct support,

\footnotetext{
${ }^{104}$ Peter Trepte, supra note 15 , at 121.

105 Jean-Jacques Verdeaux, The World Bank and Public Procurement: Improving Aid Effectiveness and Addressing Corruption, 2006 Pub. Proc. L. Rev. NA179.

${ }^{106} \mathrm{Id}$.

${ }^{107}$ See, e.g., Laurence Chandy, It's Complicated: The Challenge of Implementing the Paris Declaration on Aid Effeciveness, Brookings, Sept. 22, 2011, https://www.brookings.edu/opinions/its-complicated-the-challenge-ofimplementing-the-paris-declaration-on-aid-effectiveness/.
} 
that assistance will be structured to preserve borrowers' decisional autonomy. When problems arise in contract formation, the Bank generally will defer to the borrower nations' own complaints system.

That said, the Bank's procurement regime remains highly prescriptive. The Bank's oversight turns largely on the Bank's perceived risk -- not necessarily on the project risks for the borrower or the affected citizens. The Bank has retained its right to prior review where borrowers use what the Bank views as inherently risky methods or criteria, such as competitive dialogue or sustainability, and those risks are clearly viewed from the Bank's perspective as a fiduciary for its shareholders.

With regard to the use of country systems -- a key pillar of the aid-effectiveness agenda -the Bank's Procurement Framework remains a promise unfulfilled. "Alternative Procurement Arrangements," the current name for the use of country systems, have still not been formalized. Jeff Gutman, a senior fellow at the Brookings Institution and former official at the Bank, remains pessimistic about the initiative's prospects:

From the first High Level Forum on Aid Effectiveness and the Rome Declaration (2003), to the Paris Declaration of the second Forum (2005), then the Accra Agenda for Action (2008) and the Busan Accord (2011), generally the OECD donors and the MDBs committed to a range of principles and initiatives. While the intensely negotiated communiques did have a significant impact on the harmonisation of policies and procedures, including for procurement, the parallel focus on the use of country systems was vague, more of a politically correct right-minded statement. As a participant in the Accra negotiations, it was clear to the current reviewer that the high-level donor officials did not have any specific target or understanding about what country systems implied whether for public financial management, environmental and social safeguards or procurement. This became evident during the various attempts at the World Bank to pursue country systems for procurement. ${ }^{108}$

What seems to be slowing Alternative Procurement Arrangements is a lingering concern with corruption. Where corruption exists," the Paris declaration noted, "it inhibits donors from relying on partner country systems."

There may, though, be a deeper problem -- an uneasy sense that allowing borrowers to use their own country systems may have a centrifugal, diffusing effect on a vigorously centralized World Bank procurement system. The same strong concerns arose in the U.S. procurement system when the Federal Aviation Administration was allowed to write its own regulations to supersede the Federal Acquisition Regulation (FAR), ${ }^{109}$ which had been unified since 1984, and more recently as "Other Transaction Authority" (a sort of blanket waiver from

\footnotetext{
${ }^{108}$ See Jeff Gutman, supra note 85, at 97.

${ }^{109}$ See, e.g., Rand Allen \& Christopher Yukins, Bid Protests and Contract Disputes Under the FAA's New Procurement System, 26 Pub. Cont. L.J. 135 (1997).
} 
the FAR) gained broader acceptance among federal agencies. ${ }^{110}$ In the U.S. system, as in the Bank, there is an abiding concern that fracturing a uniform regulatory regime will weaken the overall system.

The World Bank's new Procurement Framework is, in sum, a step on the road to reform, and not an end point. The Framework earns mixed grades when assessed against the traditional measures of aid effectiveness, but it does reflect important reforms in how the Bank oversees and directs procurement in Bank-financed projects, and in how the Bank accommodates and nurtures procurement systems in the developing world.

${ }^{110}$ See, e.g., Scott Maucione, OTA Contracts Are the New Cool Thing in DoD Acquisition, Oct. 19, 2017 , https://federalnewsradio.com/acquisition/2017/10/ota-contracts-are-the-new-cool-thing-in-dod-acquisition/. 